\title{
Effects of the Mammary Gland on Functional Capacities of Blood Mononuclear Leukocyte Populations from Periparturient Cows ${ }^{1}$
}

\author{
B. J. Nonnecke, K. Kimura, J. P. Goff, and M. E. Kehrli, Jr. ${ }^{2}$ \\ Periparturient Diseases of Cattle Research Unit, \\ USDA, ARS, National Animal Disease Center, Ames, IA 50010-0070
}

\begin{abstract}
The composition and functional capacity of peripheral blood mononuclear leukocyte populations from dairy cows are altered substantially during the peripartal period. These changes are associated with a heightened susceptibility of the mammary gland to infection. It has been postulated that the metabolic demands associated with lactogenesis may impact negatively leukocyte function during the periparturient period. In the present study, serum immunoglobulin $\mathrm{G}_{1}$ concentration and functional capacities of peripheral blood mononuclear leukocytes from intact $(\mathrm{n}=6)$ and mastectomized ( $\mathrm{n}$ $=6$ ) periparturient Jersey cows were evaluated and compared. Cell function assessments included lymphocyte proliferation, immunoglobulin $\mathrm{M}$ secretion, and interferon- $\gamma$ secretion by unstimulated and pokeweed mitogen stimulated mononuclear leukocytes. Data were summarized as mean responses for 5 -d periods beginning $21 \mathrm{~d}$ prepartum and concluding at $19 \mathrm{~d}$ postpartum. The progressive decrease in serum immunoglobulin $\mathrm{G}$ in intact but not mastectomized cows before parturition likely was attributable to the selective uptake of this isotype by the mammary gland. Lymphocyte proliferation and secretion of interferon- $\gamma$ and polyclonal IgM by mitogen-stimulated leukocytes from intact cows decreased during the 15 -d period before calving, reaching a nadir at 0 to $4 \mathrm{~d}$ postpartum. From 5 to $19 \mathrm{~d}$ postpartum, these functions often were comparable to those observed 2 to 3 wk prepartum. Functions of leukocytes from mastectomized cows did not change during the study period, although they often were of lower magnitude than those of cells from nonlactating
\end{abstract}

Received November 4, 2002.

Accepted February 21, 2003.

Corresponding author: B. J. Nonnecke; e-mail: bnonneck@nadc. ars.usda.gov.

${ }^{1}$ Names are necessary to report factually on available data; however, the USDA neither guarantees nor warrants the standard of the product, and use of the name by the USDA implies no approval of the product to the exclusion of others that may also be suitable.

${ }^{2}$ Present address: Pfizer Global Research and Development, Veterinary Medicine Pharmaceutical Discovery, 9303 South Carlisle Street, Terre Haute, IN 47808. cows. These results reconfirm the occurrence of a generalized reduction in blood mononuclear leukocyte function during the periparturient period. They also suggest that the reduction in leukocyte function during the period may be, in part, due to the physiologic demands imposed on the dairy cow by the lactating mammary gland.

(Key words: interferon, lymphocyte, mammary gland, periparturient immunosuppression)

Abbreviation key: 1,25-(OH) ${ }_{2} \mathbf{D}_{3}=1,25$-dihydroxyvitamin $\mathrm{D}_{3}, \mathbf{I F N}=$ interferon, $\mathbf{I g}=$ immunoglobulin, $\mathbf{I L}=$ interleukin, $\mathbf{M H C}=$ major histocompatibility complex, PBMC = peripheral blood mononuclear cells, $\mathbf{P W M}=$ pokeweed mitogen.

\section{INTRODUCTION}

During the periparturient period, the dairy cow experiences a state of natural immunosuppression that is associated with a heightened susceptibility to infectious disease (Kehli and Harp, 2001). This condition is characterized by reduced bactericidal capacity of blood polymorphonuclear leukocytes (Kehrli et al., 1989a; Kehrli and Goff, 1989; Detilleux et al., 1995) and responsiveness of blood lymphocytes to mitogenic stimulation (Kashiwazaki et al., 1985; Ishikawa, 1987; Kehrli et al., 1989b; Detilleux et al., 1995). Cytokine activities of leukocytes in the circulation and mammary gland (i.e., secreted milk and lymph nodes) also are altered during this physiological transition (Sordillo et al., 1991, 1995; Ametaj et al., 2000). In addition, peripartal changes in Ig [i.e. antigen-specific immunoglobulin (Ig) and polyclonal IgM] producing capacity of B cells have been reported (Stabel et al., 1991; Nagahata et al., 1992; Detilleux et al., 1995).

Compositional changes in blood and mammary mononuclear leukocyte populations during the periparturient period are well characterized (Harp et al., 1991; Park et al., 1992; VanKampen and Mallard 1997; Yang et al., 1997; Kimura et al., 1999; Yamaguchi et al., 1999). Linkages between function and the phenotypic profile of lymphocyte populations in postpartal cows have been suggested (Sordillo et al., 1997). Based on 
this research, it appears that lower percentages of $\mathrm{T}$ lymphocytes during the postpartum period are associated with diminished mitogen-stimulated proliferation and spontaneous cytotoxic activity when compared to cells from midlactation cows. It has been hypothesized that bovine $\mathrm{CD} 4^{+} \mathrm{T}$ cells express a T-helper-2 phenotype (i.e., characteristic of a humoral immune response) during the periparturient period and a T-helper-1 phenotype (i.e., characteristic of a cell-mediated immune response) at midlactation (Sordillo et al., 1997; Kehrli and Harp, 2001). Nagahata et al. (1992) found no changes in the number of circulating B cells during the periparturient period although antibody-producing activity of this population was reduced relative to the activity of B cells obtained $14 \mathrm{~d}$ after parturition, suggesting humoral immunity also may be compromised in the periparturient cow. These findings indicate that alterations in the proportion of lymphocyte subsets may affect the functional capacity of the immune system of the periparturient cow and possibly its susceptibility to microbial challenge. These findings also suggest that the functional significance of these changes needs clarification.

Factors contributing to the apparent reduction in the functional capacity of peripheral blood mononuclear cells (PBMC) and heightened susceptibility to infectious disease during the periparturient period are likely diverse and interdependent. The most influential of these likely include hormonal and metabolic demands of pregnancy and lactation as well as the physiologic stress and associated increase in blood cortisol that occurs at calving (Lloyd 1983; Mallard et al., 1998; Kehrli and Harp, 2001). Corticosteroids, as an example, cause a state of immunosuppression in dairy cattle that is characterized by alterations in both the functional capacity and phenotype of PBMC populations (Burton and Kehrli, 1996; Nonnecke et al., 1997). Recent evidence indicates that the glucocorticoid receptor in bovine PBMC is down regulated in association with increased adrenal secretion of cortisol at calving (Preisler et al., 2000). Because this receptor is autoregulatory in many cell types, changes in receptor expression induced by the stress of calving may contribute to altered immune cell function and heightened disease susceptibility during the immediate postpartum period.

The biologically active metabolite of vitamin $\mathrm{D}, 1,25$ -

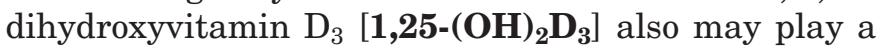
role in periparturient immunosuppression. Because lymphocytes exposed to $1,25-(\mathrm{OH})_{2} \mathrm{D}_{3}$ produce less IFN$\gamma$ and interleukin-(IL)-2, and more IL-4, IL-5, and IL10 (Daynes et al., 1996), the periparturient surge in plasma 1,25-(OH) ${ }_{2} \mathrm{D}_{3}$ (Goff et al., 2002) associated with onset of lactation may contribute to the reduced capacity of bovine lymphocytes to produce IFN- $\gamma$ (Ametaj et al., 1996; Ametaj et al., 2000; Sordillo et al., 1991). Interestingly, polyclonal and antigen-specific Ig secretion by bovine B cells is enhanced in vitro (Nonnecke et al., 1992) and in vivo (Reinhardt et al., 1999) by $1,25-(\mathrm{OH})_{2} \mathrm{D}_{3}$. These data suggest that $1,25-(\mathrm{OH})_{2} \mathrm{D}_{3}$ promotes a T-helper-2 bias in the adaptive immune response of the periparturient dairy cow.

Objectives of the present study were to evaluate functional capacities of PBMC from periparturient dairy cows and, secondly, determine whether changes in function could be, at least in part, attributable to the presence of a functional mammary gland. To achieve this objective, functions of PBMC from intact and mastectomized periparturient Jersey cows were evaluated in vitro. Leukocyte functions considered in this study serve as important indicators of the dairy cow's capacity to mount an effective, adaptive (i.e., humoral and cellular) immune response. Mononuclear leukocyte functions tested in this study also modulate phagocytic activities associated with innate immune responses.

\section{MATERIALS AND METHODS}

\section{Cows and Treatments}

Twelve periparturient Jersey cows from 6 to $9 \mathrm{yr}$ of age, in their third or greater pregnancy, were utilized in this study. Six were mastectomized at 3 to 5 mo of pregnancy and allowed to heal as described previously (Goff et al., 2002). Six intact cows of similar age to the mastectomized cows and expected to calve about the same time as the mastectomized cows were used as negative controls for surgery. These cows were nonlactating for 8 to $9 \mathrm{wk}$ prepartum and were fed the same diets as mastectomized cows for the last 8 wk of pregnancy. Sham surgery was not performed on intact animals.

Pregnant cows were housed in a free-stall barn. Two to three days before calving, they were moved to maternity pens. Cows were fed alfalfa-grass hay and grain concentrate mix ad libitum with access to a mineral salt block until 3 wk before the expected calving date. From 3 wk prepartum until the conclusion of the trial, intact and mastectomized cows were fed a TMR consisting of alfalfa hay and a grain mix high in dietary cations. They were also supplemented with 125,000 IU of retinyl palmitate and $2000 \mathrm{IU}$ of DL- $\alpha$-tocopheryl acetate/d. Beginning approximately 3 wk before the expected calving date and continuing to $3 \mathrm{wk}$ after parturition, cows were bled by jugular venipuncture twice weekly (i.e., Tuesday and Friday). In addition, nonlactating, nongravid Jersey $(n=4)$ cows were bled concurrently with the periparturient cows. During the experimental period, these cows were housed indoors in free stalls. Animal-related procedures were approved by the 
Animal Care and Use Committee of the USDA-ARSNational Animal Disease Center, Ames, Iowa.

\section{Measurement of Serum IgG}

Concentrations of IgG in serum samples were determined by a modification of the ELISA used to determine Ig concentrations in supernatants from mitogen- and antigen-stimulated PBMC cultures (Nonnecke et al., 1992). Standards consisted of serially diluted, purified bovine IgG (Jackson ImmunoResearch Labs. Inc., West Grove, PA). Goat polyclonal antibody to bovine $\operatorname{IgG}_{1}$ (VMRD, Inc., Pullman, WA) was used as the detection antibody. Pooled serum from adult dairy cows served as a positive control and heat-inactivated fetal bovine serum (Hyclone) served as a negative control.

\section{PBMC Recovery and Enrichment}

Mononuclear cells were isolated and enriched from peripheral blood samples by density-gradient centrifugation as described previously (Nonnecke et al., 1991). The PBMC were resuspended in HEPES-buffered RPMI-1640 medium (Gibco Laboratories, Grand Island, $\mathrm{NY}$ ) with $2 \mathrm{~m} M$ L-glutamine (Sigma Chemical Co., St. Louis, MO), antibiotics ( $100 \mathrm{U} / \mathrm{ml}$ of penicillin $\mathrm{G}$ sodium and $100 \mu \mathrm{g} / \mathrm{ml}$ of streptomycin sulfate), and antimycotics $(0.25 \mu \mathrm{g} / \mathrm{ml}$ of amphotericin B, Gibco Laboratories).

\section{In Vitro DNA Synthesis by PBMC}

Evaluation of lymphocyte proliferation (i.e., DNA synthesis) by resting (i.e., unstimulated) and mitogenstimulated PBMC was performed as reported previously (Nonnecke et al., 1991). Briefly, cell cultures were established in flat-bottomed 96-well tissue culture plates (Costar, Cambridge, MA) inoculated with $1.0 \times$ $10^{6} \mathrm{PBMC} / \mathrm{ml}$ in a final volume of $200 \mu \mathrm{l}$. All cultures contained $5 \%$ fetal bovine serum (vol/vol) (Hyclone Laboratories, Inc., Logan, UT). Synthesis of DNA by PBMC was assessed in cultures stimulated with pokeweed mitogen (PWM, Sigma Chemical Co.) at 0.0, 0.2, 2.0, and $20.0 \mu \mathrm{g} / \mathrm{ml}$ of culture. Triplicate cultures were incubated for a total of $66 \mathrm{~h}$ at $39^{\circ} \mathrm{C}$ in humidified atmosphere of $5 \% \mathrm{CO}_{2}$ and pulsed at $48 \mathrm{~h}$ with $18.5 \mathrm{kBq}$ of [methyl- ${ }^{3} \mathrm{H}$ ]-thymidine (Amersham Corp., Arlington Heights, IL) in $50 \mu$ l of RPMI-1640 medium. Cells were harvested onto glass fiber filters (model PHD cell harvester, Cambridge Technology, Watertown, MA), and the retained radioactivity was measured by liquid scintillation spectrophotometry (LS8000 liquid scintillation counter, Beckman Instruments, Fullerton, CA). Synthesis of DNA by resting and mitogen stimulated cells was expressed as counts per minute.

\section{In Vitro Production and Measurement of IgM Secretion}

Secretion of polyclonal IgM by PBMC was evaluated in cell cultures established in flat-bottom, 24-well tissue culture plates. Individual wells were inoculated with 1 $\times 10^{6} \mathrm{cell} / \mathrm{s} / \mathrm{ml}$ in a total culture volume of $1.5 \mathrm{ml}$. Culture medium consisted of RPMI-1640 with 5\% (vol/vol) fetal calf serum (Hyclone). Secretion of polyclonal IgM was evaluated in PBMC cultures stimulated with PWM at $0.0,0.06$, and $0.12 \mu \mathrm{g} / \mathrm{ml}$. Duplicate cultures were incubated at $39^{\circ} \mathrm{C}$ in a $5 \% \mathrm{CO}_{2}$ atmosphere for $14 \mathrm{~d}$. Polyclonal IgM concentrations in supernatants from 14-d cultures of PBMC was measured by ELISA as described previously (Nonnecke et al., 1992). The concentration $(\mu \mathrm{g} / \mathrm{ml})$ of IgM in supernatants from resting and stimulated PBMC cultures was quantified by comparison of absorbances of test samples with absorbances of IgM standards within a linear curve fit.

\section{In Vitro Production and Measurement of Interferon- $\gamma$}

Interferon (IFN)- $\gamma$ secretion by PBMC was evaluated in cell cultures established in flat-bottom, 96-well tissue culture plates. Individual wells were inoculated with 5 $\times 10^{6}$ cells $/ \mathrm{ml}$ in a total volume of $200 \mu \mathrm{l}$ of RPMI 1640 medium with FCS (5\% vol/vol). Cultures were stimulated with $0,0.2,2.0$, and $20 \mu \mathrm{g}$ of $\mathrm{PWM} / \mathrm{ml}$ of culture medium and incubated $72 \mathrm{~h}$ at $39^{\circ} \mathrm{C}$ in an atmosphere of $5 \% \mathrm{CO}_{2}$. Interferon- $\gamma(\mathrm{ng} / \mathrm{ml})$ in culture supernatants was quantified by an IFN- $\gamma$ capture ELISA. Reagents and protocol for this assay have been described previously (Ametaj et al., 1996). Briefly, mouse antirBoIFN- $\gamma$ was employed as the capture antibody and rabbit anti-IFN- $\gamma$ as the detection antibody. Binding of the detection antibody was determined using a biotinylated goat anti-rabbit Ig, horse radish peroxidase-conjugated streptavidin-biotinylated complex and 2 '-azinobis-3-ethyl-benzthiazoline. Internal standards consisted of serial dilutions of recombinant bovine IFN- $\gamma$ ( 0 to $8 \mathrm{ng} / \mathrm{ml}$ ). Test samples were serially diluted 1:2. Absorbance of test and standard wells was read at 405 (test filter) and $490 \mathrm{~nm}$ (reference filter) using an automated ELISA plate washer and reader (Dynatech MR7000, Dynatech Laboratories Inc., Alexandria, VA). Interferon- $\gamma$ in test samples was determined from a standard curve of absorbance regressed on the IFN- $\gamma$ concentration for the dilution of the test sample that yielded absorbance readings that fell within the linear portion of the curve. The concentration $(\mathrm{ng} / \mathrm{ml})$ of IFN$\gamma$ was calculated by multiplying the value from the standard curve by the dilution factor. 


\section{Statistical Analysis}

Periparturient cow data were summarized as mean responses for 5 -d intervals beginning $21 \mathrm{~d}$ prepartum and concluding at $19 \mathrm{~d}$ postpartum. Means were generated for the following time periods: -21 to $-16 \mathrm{~d},-15$ to $-11 \mathrm{~d},-10$ to $-6 \mathrm{~d},-5$ to $-1 \mathrm{~d}$ prepartum, and 0 to 4 d, 5 to $9 \mathrm{~d}, 10$ to $14 \mathrm{~d}$, and $15 \mathrm{~d}$ to $19 \mathrm{~d}$ postpartum. Data were assessed for normality prior to statistical analysis. Arithmetic and log10-transformed data were analyzed as a split-plot with repeated measures ANOVA using Statview software (version 5.0, SAS Institute, Inc., Cary, NC). The statistical model included effects of treatment (intact vs. mastectomized), time (days relative to parturition), and the interaction of treatment and time on serum Ig concentrations and functional capacities of PBMC populations in vitro. Fisher's protected-LSD test was applied when significant effects $(P<0.05)$ were detected by the model. Responses of individual nonlactating cows for each time period were averaged, and the means of the four individuals were used to calculate the mean response of this group during the experimental period $(n=4)$.

Phenotype data for circulating leukocytes [i.e., B cell, monocyte, $\mathrm{T}$ cell subset (i.e., CD3+, $\mathrm{CD} 4^{+}, \mathrm{CD} 8^{+}, \gamma \delta \mathrm{T}$ cell receptor $(\mathbf{T C R})^{+}$lymphocytes), IL2-receptor+ cells, major histocompatibility complex (MHC) class II+ cell percentages and CD4: CD8 ratio] of cows on study were provided by Kimura et al. (2002). Pearson's productmoment correlations were computed between phenotypic variables describing the composition of PBMC population and functional capacities (i.e., mitogen-induced DNA-synthesis, IgM secretion, and IFN- $\gamma$ secretion) of this population. Correlations were based on 24 observations made beginning $5 \mathrm{~d}$ prepartum and until $4 \mathrm{~d}$ postpartum. Intact and mastectomized cows were included in the analysis.

\section{RESULTS AND DISCUSSION}

\section{General Observations}

The impact of the mammary gland on milk fever and hormonal status of periparturient cows utilized in the present study has been described by Goff et al. (2002). All intact cows developed milk fever within $24 \mathrm{~h}$ of calving and were given a calcium solution intravenously. Mastectomy eliminated hypocalcemia and increases in plasma 9,13-di-cis-retionic acid, and reduced, but did not eliminate decreases in plasma phosphorous, ?-tocopherol, and $\beta$-carotene associated with parturition in intact cows. Results indicate that hypocalcemia and increases in plasma $1,25-(\mathrm{OH})_{2} \mathrm{D}_{3}$ concentrations in peripartal cows are solely a result of the calcium demands of lactation.
Effects of the presence of the mammary gland on the composition of PBMC populations have been described in a companion paper (Kimura et al., 2002). Overall, percentages of $\mathrm{CD}^{+}, \mathrm{CD}^{+}$, and $\gamma \delta$-receptor ${ }^{+} \mathrm{T}$ cell subsets decreased and the percentage of monocytes in the circulation of intact cows increased during the peripartal period. In mastectomized cows, comparable changes in PBMC populations were less profound or absent. Because an essential function of this population is to assure development of a competent, adaptive immune response, the authors suggest that phenotypic changes in $\mathrm{T}$ cell subsets seen in intact but not mastectomized cows affect negatively infectious disease resistance.

\section{Effects of the Mammary Gland on Serum IgG}

Effects of the presence of the mammary gland on serum IgG concentrations are presented in Table 1 and Figure 1. Longitudinal fluctuations in serum IgG were not significant $(P=0.78$, Table 1$)$ in mastectomized individuals. Serum IgG concentrations in intact cows, however, decreased $(P<0.001)$ from $13.4 \mathrm{~g} / \mathrm{L}$ at -21 to $-16 \mathrm{~d}$ prepartum to $7.9 \mathrm{~g} / \mathrm{L}$ at -5 to $-1 \mathrm{~d}$ prepartum (Figure 1). During the postpartum period, IgG in intact cows increased $(P<0.05)$ progressively and averaged $11.2 \mathrm{~g} / \mathrm{L}$ by 15 to $19 \mathrm{~d}$ postpartum. The decline in IgG concentrations immediately before and just after calving likely was attributable to the selective uptake of the $\mathrm{IgG}_{1}$ isotype by the mammary gland. Transport of $\mathrm{IgG}_{1}$ from the blood into the colostrum is known to be mediated by $\mathrm{IgG}_{1}$-specific $\mathrm{Fc}$ receptors on the membranes of alveolar epithelial cells in the mammary gland (Brandon et al., 1971).

\section{Effects of a Mammary Gland on PBMC Function in Periparturient Cows}

The battery of in vitro tests used in the present study to evaluate the functional capacity of PBMC populations from nonlactating and periparturient cows provides an in vitro correlate of the responsiveness of the bovine immune system. In these tests, cells were unstimulated or stimulated with the plant lectin, PWM. Bovine PBMC stimulated with PWM undergo a proliferative response characterized by increased numbers of $\mathrm{CD}^{+}, \mathrm{CD}^{+}$, and $\gamma \delta \mathrm{TCR}+\mathrm{T}$ cell subsets, B cells, and cells expressing IL-2 receptor and MHC class II antigen (Franklin et al., 1994). Functional effects of PWM stimulation include increased [methyl- ${ }^{3} \mathrm{H}$ ]-thymidine incorporation (Kehrli et al, 1989) and secretion of IgM and IFN- $\gamma$ (Ametaj et al., 1996; Nonnecke et al., 1997).

Periparturient immunosuppression in the dairy cow is characterized by longitudinal changes in composition and function of PBMC populations with the nadir of 
Table 1. Probabilities (P) that the effect of sampling period on serum immunoglobulin (Ig) concentrations and leukocyte function variables was not significant during the experimental period.

\begin{tabular}{|c|c|c|}
\hline \multirow[b]{2}{*}{ Variable } & \multicolumn{2}{|c|}{ Treatment group } \\
\hline & Intact, $\mathrm{n}=6$ & Mastectomized, $\mathrm{n}=6$ \\
\hline & $P$ & $P$ \\
\hline Serum IgG & $<0.001$ & NS (0.78) \\
\hline \multicolumn{3}{|l|}{ DNA-synthesis in vitro } \\
\hline Not stimulated & $\mathrm{NS}^{3}(0.57)$ & NS (0.78) \\
\hline PWM, $0.2 \mu \mathrm{g} / \mathrm{ml}$ & $<0.01$ & NS $(0.36)$ \\
\hline PWM, $2 \mu \mathrm{g} / \mathrm{ml}$ & $<0.01$ & NS $(0.60)$ \\
\hline PWM, $20 \mu \mathrm{g} / \mathrm{ml}$ & NS $(0.09)$ & NS $(0.60)$ \\
\hline \multicolumn{3}{|c|}{ Polyclonal IgM secretion in vitro } \\
\hline Not stimulated & NS (0.88) & NS $(0.60)$ \\
\hline PWM, $0.06 \mu \mathrm{g} / \mathrm{ml}$ & $<0.01$ & NS (0.33) \\
\hline PWM, $0.12 \mu \mathrm{g} / \mathrm{ml}$ & $<0.05$ & NS $(0.88)$ \\
\hline \multicolumn{3}{|c|}{ Interferon- $\gamma$ secretion in vitro ${ }^{2}$} \\
\hline PWM, $0.2 \mu \mathrm{g} / \mathrm{ml}$ & NS (0.12) & NS (0.79) \\
\hline PWM, $2 \mu \mathrm{g} / \mathrm{ml}$ & $<0.05$ & NS (0.99) \\
\hline PWM, $20 \mu \mathrm{g} / \mathrm{ml}$ & $<0.05$ & NS (0.77) \\
\hline
\end{tabular}

${ }^{1}$ Leukocyte cultures were unstimulated or stimulated by pokeweed mitogen (PWM) in vitro.

${ }^{2}$ Interferon- $\gamma$ was not detectable in supernatants from unstimulated cultures.

${ }^{3}$ Not significant (NS). $P$-values $\geq 0.05$ are in brackets.

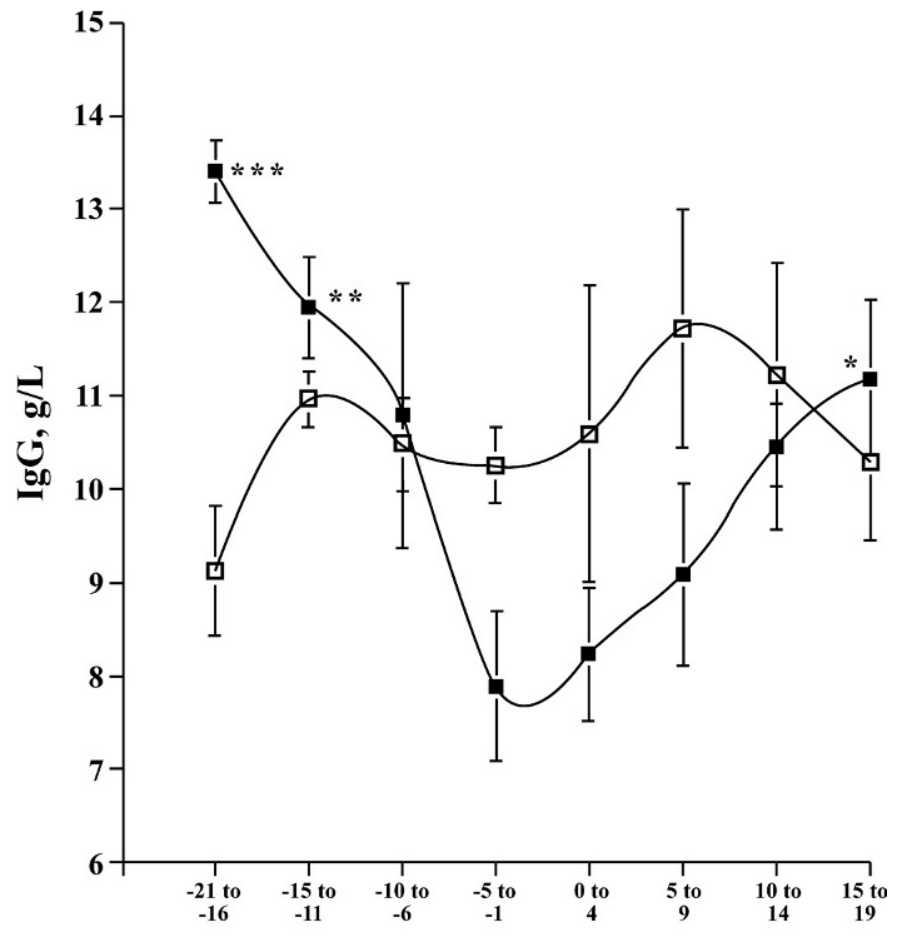

Days relative to parturition

Figure 1. Immunoglobulin (Ig) G concentrations in serum from intact (closed squares, $\mathrm{n}=6$ ) and mastectomized (open squares, $\mathrm{n}=$ 6) periparturient dairy cows. Values represent mean $\left( \pm\right.$ SEM) $\operatorname{IgG}_{1}$ concentrations during 5 -d periods, beginning $21 \mathrm{~d}$ prepartum and concluding at $19 \mathrm{~d}$ postpartum. Asterisks indicate periods within a treatment that differed from 0 - to 4 -d period, $* P<0.05, * * P<.01$, $* * * P$ $<0.001$. functional capacity occurring in the first week after parturition. In the present study, longitudinal changes in PWM-induced thymidine incorporation, and secretion of IgM and IFN- $\gamma$ by PBMC from intact periparturient cows were significant $(P<0.05)$ from $-21 \mathrm{~d}$ prepartum to $19 \mathrm{~d}$ postpartum (Table 1 ). These changes typically were characterized by a progressive reduction in function as parturition approached with the functional nadir occurring 0 to $4 \mathrm{~d}$ after calving (Figures 2 to 4). Within 2 to 3 wk postpartum, functions often were comparable to those observed at 2 to 3 wk prepartum. Although time-dependent fluctuations in the functional capacities of PBMC from mastectomized individuals were evident, at no time were they significant $(P>0.05$, Table 1). These data clearly indicate that the mammary gland and metabolic demands associated with lactation contribute to functional hyporesponsiveness of mononuclear cells from recently calved dairy cows. Hyporesponsiveness of this leukocyte population likely compromises the cow's capacity to fight infections at virtually any site in the body (i.e., gastrointestinal, respiratory, reproductive, mammary gland).

Time-dependent changes in mitogen-induced DNA synthesis are shown in Figure 2. Rates of thymidine incorporation in unstimulated (i.e., resting) PBMC from intact and mastectomized cows were unaffected by parturition and were comparable to rates in parallel cultures of cells from nonlactating cows. Rates of thymidine incorporation in PWM $(0.2$ and $2.0 \mu \mathrm{g} / \mathrm{ml})$-stimulated cells from intact cows, however, decreased progressively during the 10 -d period before calving and were lowest at 0 to $4 \mathrm{~d}$ postpartum (Figure $2 \mathrm{~b}$ and $2 \mathrm{c}$ ). As an example, mean incorporation rates in cultures 

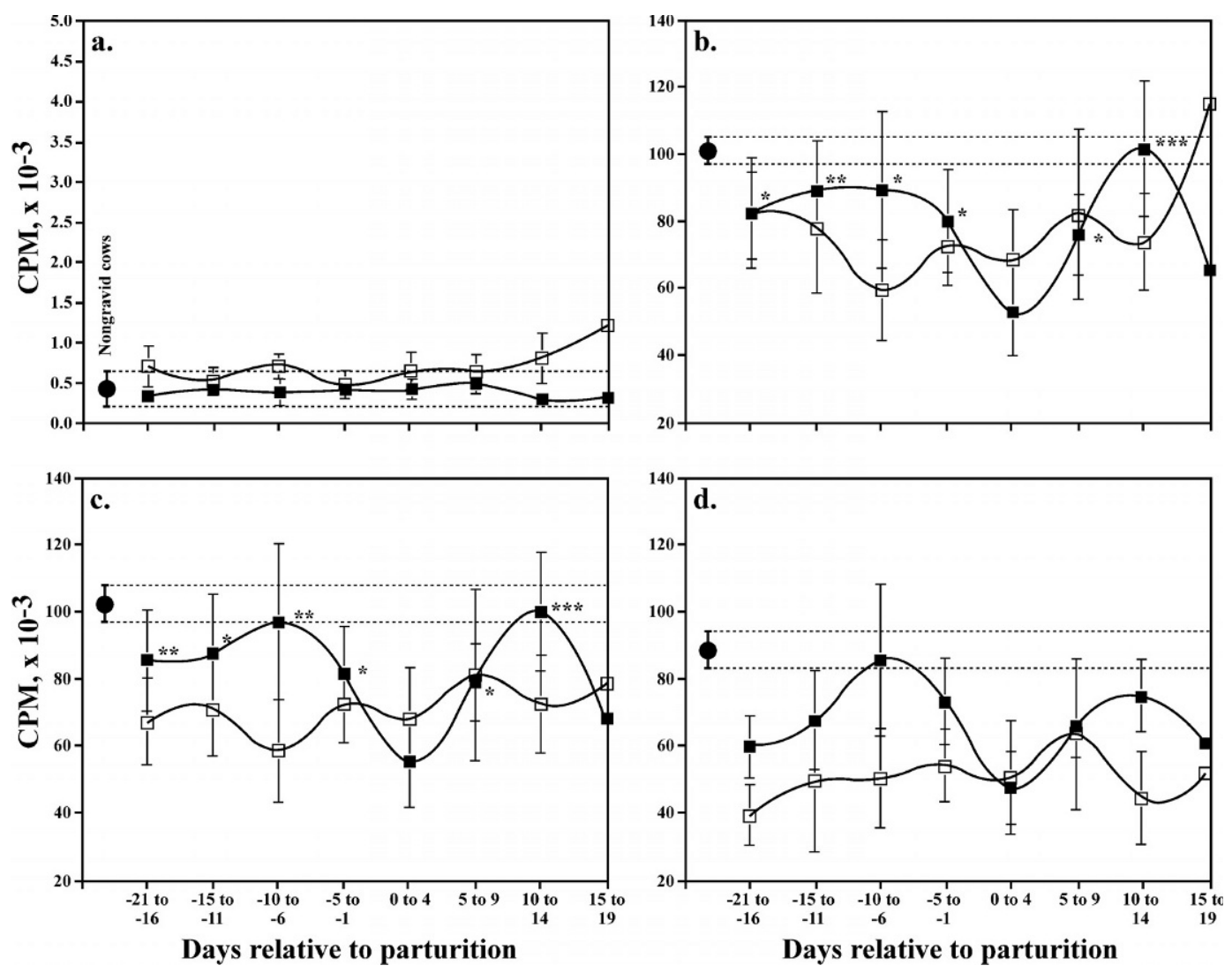

Figure 2. Blastogenic [counts per minute $(\mathrm{CPM}) \times 10^{-3}$ ] responses of blood mononuclear cells stimulated with 0 (a), $0.2(\mathrm{~b}), 2.0(\mathrm{c})$, and 20 (d) $\mu \mathrm{g}$ of pokeweed mitogen $/ \mathrm{ml}$. Responses of cells from intact (closed squares, $\mathrm{n}=6$ ) and mastectomized (open squares, $\mathrm{n}=6$ ) periparturient cows, and nonlactating cows (closed circle, $\mathrm{n}=4$ ) are shown. Values represent mean $( \pm \mathrm{SEM})$ responses during 5 -d periods beginning $21 \mathrm{~d}$ prepartum and concluding at $19 \mathrm{~d}$ postpartum. Asterisks indicate time periods within a treatment that differed from the 0- to 4-d period, $* P<0.05, * * P<0.01, * * * P<0.001$.

stimulated with $2.0 \mu \mathrm{g} / \mathrm{ml}$ PWM decreased $42 \%(P<$ 0.001 ), from $97,000 \mathrm{CPM}$ at -10 to $-6 \mathrm{~d}$ prepartum to $55,980 \mathrm{CPM}$ at 0 to $4 \mathrm{~d}$ postpartum (Figure 2c). During the same period, mean incorporation rates for cells from mastectomized cows were not different $(P>0.05)$ and ranged from 59,111 to 68,630 CPM (Figure 2c). Previous studies have reported similar reductions in mitogeninduced DNA-synthesis within the first $10 \mathrm{~d}$ after calving (Kashiwasaki et al., 1985; Ishikawa, 1987; Kehrli et al., 1989). Although PWM-induced DNA synthesis in cells from mastectomized cows remained stable during the periparturient period, it frequently was of lower magnitude than in cells from nonlactating cows (Figure 2). These data and those indicating that PWM-induced IgM secretion by cells from periparturient cows was less than secretion by cells from nonlactating cows during most of the study period (Figure $3 \mathrm{~b}$ and $3 \mathrm{c}$ ) suggest that factors unrelated to the mammary gland (e.g., endocrinological and metabolic consequences of pregnancy and energy balance) also affect PBMC function.
Assays quantifying Ig production by PBMC stimulated with a T-dependent, B cell mitogens and antigens are important tools for estimating B cell function in vivo. Using these approaches, Ig secretion by B cells from the peripheral blood of recently calved cows has been shown to be reduced compared to cells from cows in later stages of lactation (Stabel et al., 1991; Nagahata et al., 1992; Detilleux et al., 1995). Effects of mastectomy on secretion of polyclonal IgM by unstimulated and PWM-stimulated cells from periparturient cows are presented in Figure 3. Secretion of IgM by unstimulated PBMC from periparturient cows was unaffected by parturition and comparable to secretion by unstimulated cells from nonlactating cows (Figure 3a). Pokeweed mitogen-induced IgM secretion by cells from intact and mastectomized cows tended to decrease with the approach of parturition; however, the decrease was significant $(P<0.01)$ in intact cows only (Figure 3b and 3c). In both intact and mastectomized cows, IgM secretion was lowest at 0 to $4 \mathrm{~d}$ postpartum. In intact 

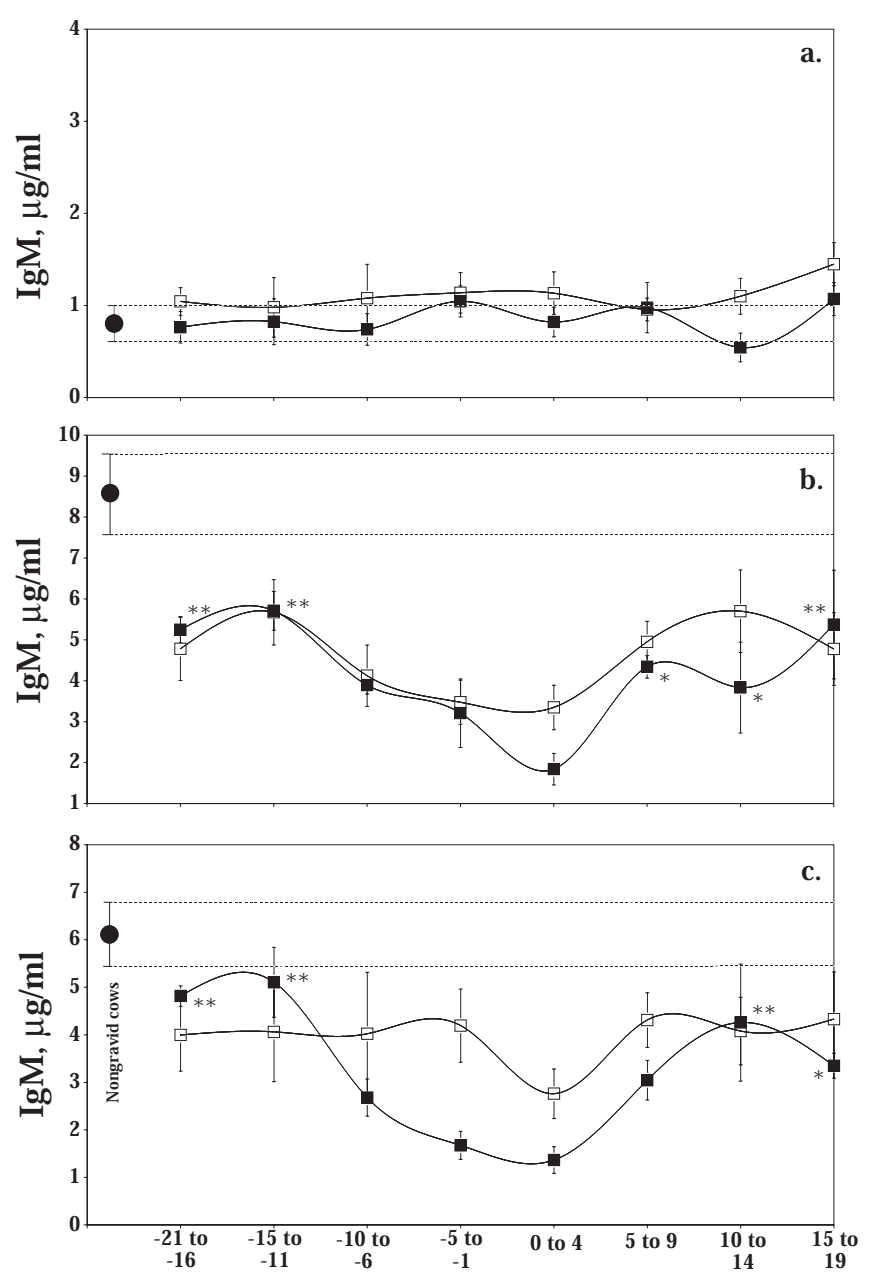

Days relative to parturition

Figure 3. Immunoglobulin M (IgM) responses of blood mononuclear cells stimulated with 0 (a), 0.06 (b), and 0.12 ?g/ml (c) of pokeweed mitogen $/ \mathrm{ml}$. Responses of cells from intact (closed squares, $n=$ 6 ) and mastectomized (open squares, $\mathrm{n}=6$ ) periparturient cows, and nonlactating cows (closed circle, $n=4$ ) are shown. Values represent the mean $( \pm \mathrm{SEM})$ responses during 5 -d periods beginning $21 \mathrm{~d}$ prepartum and concluding at $19 \mathrm{~d}$ postpartum. Asterisks indicate time periods within a treatment that differed from the 0 - to 4 -d period, $* P<0.05, * * P<0.01$.

cows, mean IgM secretion by cultures stimulated with $0.06 \mu \mathrm{g} / \mathrm{ml}$ of PWM declined 68\% $(P<0.01)$, from 5.71 $\mu \mathrm{g} / \mathrm{ml}$ at -15 to $-11 \mathrm{~d}$ prepartum to $1.84 \mu \mathrm{g} / \mathrm{ml}$ at 0 to $4 \mathrm{~d}$ postpartum. In the postpartum period, secretion increased progressively and by 15 to $19 \mathrm{~d}$ postpartum was maximal $(P<0.001)$ at $5.38 \mu \mathrm{g} / \mathrm{ml}$. These data indicate that the mammary gland contributes to the reduction in $\mathrm{B}$ cell function observed in recently calved cows.

Interferon- $\gamma$ is synthesized by activated $\mathrm{T}$ cells and natural killer cells. Because this cytokine induces an antiviral state, promotes expression of $\mathrm{MHC}$ antigens,
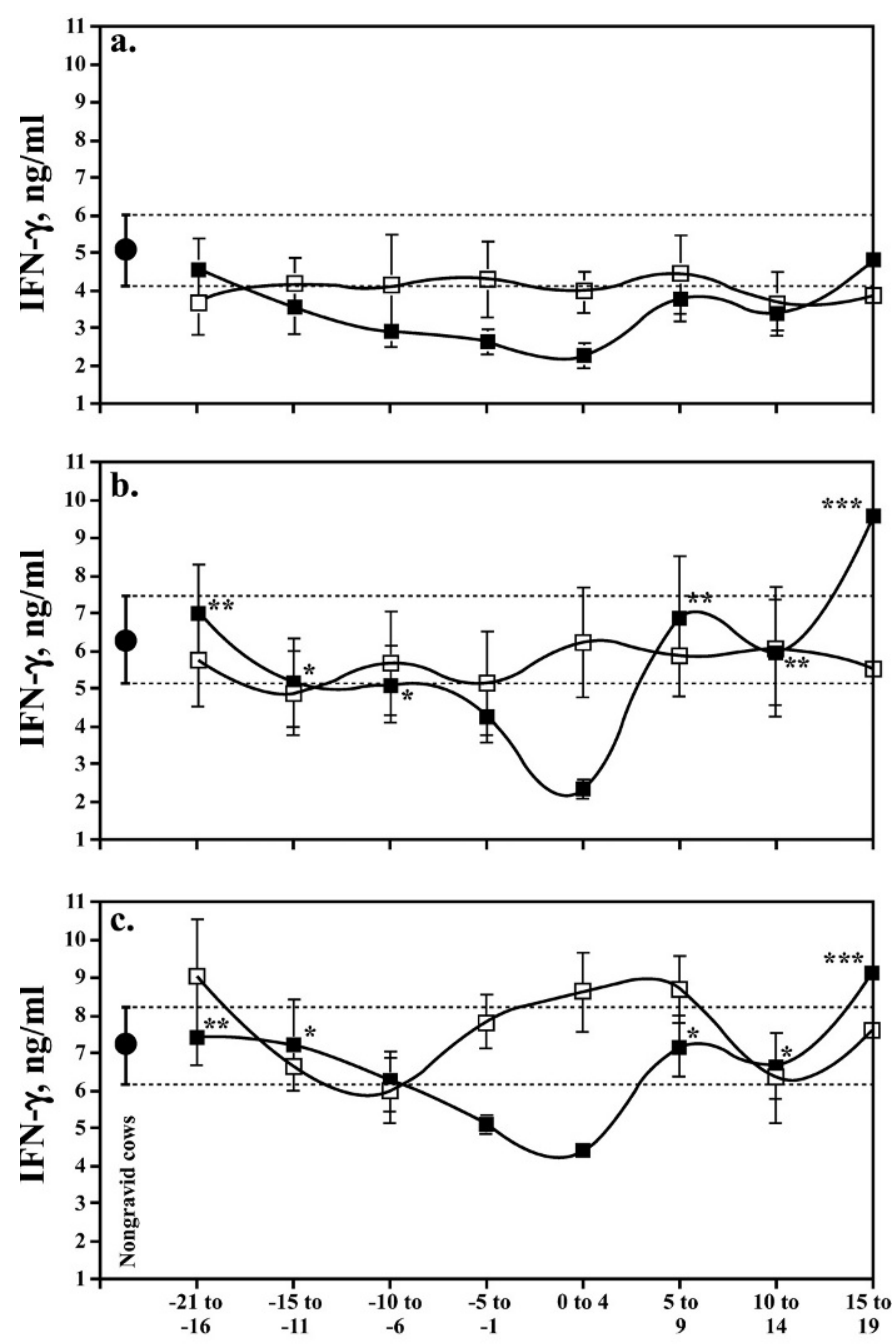

Days relative to parturition

Figure 4. Interferon (IFN)- $\gamma$ responses of blood mononuclear cells stimulated with 0.2 (a), 2.0 (b), and $20 \mu \mathrm{g}$ (c) of pokeweed mitogen/ ml. Secretion of IFN- $\gamma$ by cells from intact (closed squares, $n=6$ ) and mastectomized (open squares, $\mathrm{n}=6$ ) periparturient cows (single symbols, $\mathrm{n}=4$ ), and nonlactating cows (closed circle, $\mathrm{n}=4$ ) are shown. Values represent mean $( \pm \mathrm{SEM})$ responses during 5 -d periods beginning $21 \mathrm{~d}$ prepartum and concluding at $19 \mathrm{~d}$ postpartum. Asterisks indicate time periods that differed from the 0 - to 4 -d period within a treatment, $* P<0.05,{ }^{*} P<0.01, * * * P<0.001$.

and enhances activation of macrophages, neutrophils, and natural killer cells, it is considered crucial in the development of an effective cell-mediated immune response. Numerous studies (Sordillo et al., 1991; Ishikawa et al., 1994; Ametaj et al., 2000) have demonstrated a reduction in the capacity of bovine $\mathrm{T}$ cells to secrete IFN- $\gamma$ during the immediate, postpartum period. In the study by Ametaj et al. (2000), PWM-stimulated PBMC from Holstein cows secreted 1 to $2 \mathrm{ng} / \mathrm{ml}$ of IFN- $\gamma$ from 0 to $4 \mathrm{~d}$ postpartum. Although the amount of IFN- $\gamma$ secreted at $16 \mathrm{~d}$ postpartum was greater (4.6 
$\mathrm{ng} / \mathrm{ml}, P<0.05)$, it was less than the amount of cytokine secreted $(13.1 \mu \mathrm{g} / \mathrm{ml})$ in identically prepared cultures utilizing cells from nongravid Holstein cows. In the present study, IFN- $\gamma$ secretion by unstimulated cultures was undetectable. Effects of the periparturient period on PWM-induced IFN- $\gamma$ secretion by cells from periparturient and nonlactating cows are shown in Figure 4. Intact cows demonstrated a pronounced $(P<$ $0.05)$ decline in their capacity to produce IFN- $\gamma$ with the approach of parturition (Figure $4 \mathrm{c}$ and $4 \mathrm{~d}$ ). In cultures stimulated with 2 and $20 \mu \mathrm{g} / \mathrm{ml}$ of PWM, the nadir in function occurred at 0 to $4 \mathrm{~d}$ postpartum. Interferon- $\gamma$ secretion decreased $40 \%(P<0.01)$ from $7.36 \mathrm{ng} / \mathrm{ml}$ at -21 to $-16 \mathrm{~d}$ prepartum to $4.42 \mathrm{ng} / \mathrm{ml}$ at 0 to $4 \mathrm{~d}$ postpartum in cultures stimulated with $20 \mu \mathrm{g} / \mathrm{ml}$ of PWM (Figure $4 \mathrm{c})$. Interferon- $\gamma$ responses increased $(P<0.001)$ progressively after the 0 - to 4 - $\mathrm{d}$ period and reached 9.05 $\mathrm{ng} / \mathrm{ml}$ at 15 to $19 \mathrm{~d}$ postpartum. In contrast, PWMinduced IFN- $\gamma$ responses of mastectomized cows remained unchanged (Table 1 and Figure 4) during the period and, unlike responses in DNA synthesis and IgM assays, were comparable to IFN- $\gamma$ responses of nonlactating cows. As was observed for results from DNA synthesis and Ig secretion assays, the magnitude of the reduction in IFN- $\gamma$ responses during the immediate postpartum period was influenced by the mammary gland.

Associations between cell function variables and percentages of cells expressing unique phenotypes were analyzed using data collected during periods spanning $-5 \mathrm{~d}$ prepartum to $4 \mathrm{~d}$ postpartum. Because the number of PBMC used to seed cultures was fixed, the percent composition of this population was considered a potential determinant of its functional capacity in vitro. Compositional data utilized in these analyses included percentages of B cells; monocytes; $\mathrm{CD}^{+}, \mathrm{CD}^{+}, \mathrm{CD}^{+}$, and $\gamma \delta$ TCR+ T cells; IL-2 receptor ${ }^{+}$cells, MHC class $\mathrm{II}^{+}$ cells, and the $\mathrm{CD}^{+}$: $\mathrm{CD}^{+} \mathrm{T}$ cell ratios. Associations between the composition and capacity of the PBMC population to secrete IgM were not detected. These results are similar to those reported by Nagahata et al. (1992) demonstrating a reduction in B cell function in the periparturient cow, most pronounced from 0 to $3 \mathrm{~d}$ after parturition, without concomitant change in B cell percentage. Results from the present study also suggest that $\mathrm{T}$ cell subset percentages comprising the PBMC are not associated with this population's capacity to secrete IgM.

Relatively weak associations were found between PBMC population composition and its capacity to synthesize DNA. Specifically, $\gamma \delta \mathrm{TCR}^{+}$cell percentage was positively associated with the DNA synthesis in cultures stimulated with $0.2(\mathrm{r}=0.54, P=0.027), 2.0(\mathrm{r}=$ $0.51, P=0.025)$, and $20.0(\mathrm{r}=0.42, P=0.044) \mu \mathrm{g} / \mathrm{ml}$ of PWM. In cultures stimulated with $20 \mu \mathrm{g} / \mathrm{ml}$ PWM, B cell percentage was associated $(\mathrm{r}=0.43, P=0.038)$ with DNA-synthesis. Interferon- $\gamma$ secretion also was correlated with compositional differences in the PBMC population. In cultures stimulated with $2 \mu \mathrm{g} / \mathrm{ml}$ of PWM, monocyte ( $\mathrm{r}=-0.45, P=0.026), \mathrm{CD}^{+}$cell percentage $(\mathrm{r}=0.47, P=0.02)$, and $\mathrm{CD} 4$ : $\mathrm{CD} 8$ ratio $(\mathrm{r}=0.48$, $P=0.011)$ were correlated with IFN- $\gamma$ secretion. Monocyte $(\mathrm{r}=0.50, P=0.012)$, B cell $(\mathrm{r}=0.75, P<0.0001)$, $\mathrm{CD}^{+}$cell $(\mathrm{r}=0.49, P=0.014), \mathrm{CD} 4^{+}$cell $(\mathrm{r}=0.59, P=$ $0.002)$, and $\mathrm{MHC}$ class $\mathrm{II}^{+}$cell $(\mathrm{r}=0.72, P<0.0001)$ percentages were correlated with IFN- $\gamma$ responses in cultures stimulated with PWM at $20 \mu \mathrm{g} / \mathrm{ml}$. These data imply that changes in the composition of the PBMC population during the periparturient period influence functional capacities of the population in vitro, especially responses characterized by rates of thymidine incorporation (i.e., DNA synthesis) and IFN- $\gamma$ secretion. However, these associations were relatively weak or absent (i.e., IgM secretion and PBMC composition), suggesting that PBMC function is influenced by additional factors. These likely include the direct effects of metabolic changes associated with the act of parturition and onset of lactation. These results suggest that the loss of cell function observed in the present study was not simply due to a loss of cells from the circulation.

Analysis of metabolic changes in intact and mastectomized periparturient cows has identified several lactation-specific alterations in plasma hormone and micronutrient concentrations (Goff et al., 2002) that might be linked to deficits in cell function seen in intact cows. The response of the intact cow to the calcium drain of lactation may be linked to differences between cell functions in intact and mastectomized cows. This response was characterized by a rapid decrease in plasma calcium and increase in plasma magnesium and 1,25$(\mathrm{OH})_{2} \mathrm{D}_{3}$ concentrations from -5 to $0 \mathrm{~d}$ relative to parturition followed by a return to normal levels 3 to $7 \mathrm{~d}$ postpartum (Goff et al., 2002). Because 1,25-(OH) ${ }_{2} \mathrm{D}_{3}$ suppresses proliferative (Nonnecke et al., 1993) and IFN- $\gamma$ responses (Ametaj et al., 1996, Ametaj et al., 2000) of activated bovine PBMC, it is conceivable that the observed inhibition of DNA synthesis (Figure 2) and IFN- $\gamma$ (Figure 4) secretion by cells from intact but not mastectomized cows at 0 to $4 \mathrm{~d}$ postpartum was mediated, in part, by this vitamin D metabolite. In addition to its negative effect on proliferation and IFN$\gamma$ secretion by bovine cells, $1,25-(\mathrm{OH})_{2} \mathrm{D}_{3}$ has been shown to enhance PWM-induced IgM secretion in vitro (Nonnecke et al., 1992) and antigen-specific IgG production in vivo (Reinhardt et al., 1999). Based on these observations, it might be expected that $\mathrm{B}$ cell function (i.e., IgM secretion) in intact cows would be comparable to or exceed that of mastectomized cows; however, this 
was not the case (Figure 3). These data clearly suggest that additional factors contribute to the reduction in PBMC function in recently calved cows (Kehrli and Harp, 2001).

The spike in cortisol occurring from $-2 \mathrm{~d}$ prepartum to $+3 \mathrm{~d}$ postpartum in both intact and mastectomized cows also may have impaired IgM and IFN- $\gamma$ secretion. Unlike $1,25-(\mathrm{OH})_{2} \mathrm{D}_{3}$ that appears to promote humoral immunity (i.e., T-helper-2 response), corticosteroids induce a state of generalized immunosuppression. This is supported by observations indicating that $\operatorname{IgM}$ and IFN- $\gamma$ secretion by activated bovine PBMC are inhibited by the synthetic corticosteroid, dexamethasone (Nonnecke et al., 1997). Interestingly, plasma cortisol concentrations at 1 and $2 \mathrm{~d}$ postpartum were greater (i.e., $19 \mathrm{vs} .13 \mathrm{ng} / \mathrm{ml}$ ) in intact than in mastectomized cows. Although this difference was small, the greater reduction in IgM secretion in intact cows may have been due, in part, to the sustained, higher cortisol concentrations in this group immediately after parturition (i.e., 0 to $4 \mathrm{~d}$ postpartum). Although vitamin $\mathrm{D}$ and cortisol may have contributed to the loss of PBMC function in intact cows, it must be recognized that there could be any number of additional factors not yet measured that also modulate leukocyte function in the intact, periparturient dairy cow.

Pregnancy has been postulated to result in suppression of T-helper-1 immunity and enhancement of Thelper-2 immunity (Wegman et al., 1993). Evidence indicating that bovine $\mathrm{CD} 4^{+} \mathrm{T}$ cells express a T-helper-2 phenotype at 1 to $3 \mathrm{~d}$ postpartum and a T-helper-1 phenotype at midlactation suggests the immune response is biased toward a T-helper-2 response until several days after calving (Sordillo et al., 1997). Results from the present study, however, suggest that leukocyte functions contributing to both cellular and humoral responses may be affected negatively at calving. Conceivably, the immune system of the intact cow at this time (i.e., 0 to $4 \mathrm{~d}$ postpartum) is not biased toward either a T-helper-1 or T-helper-2 response. Additional research is necessary to elucidate the mechanism(s) underlying periparturient immunosuppression.

\section{CONCLUSIONS}

Results from the present study confirm the occurrence of a generalized suppression of the adaptive-arm of the immune system of the periparturient dairy cow. The presence of the mammary gland and metabolic demands associated with the induction of lactation appear to exacerbate the negative effects of the periparturient period on the functional capacity of the PBMC population. Alterations in the composition of the PBMC population and metabolic changes associated with in- duction of lactation likely contribute to the reduction in immune cell function.

\section{ACKNOWLEDGMENTS}

Authors thank Donald McDorman and Nancy Eischen for technical support, and Norman S. Tjelmeland, Creig E. Caruth, and Eugene C. Rieks for their care of the cows used in this study.

\section{REFERENCES}

Ametaj, B. N., D. C. Beitz, T. A. Reinhardt and B. J. Nonnecke. 1996. 1,25-Dihydroxyvitamin $\mathrm{D}_{3}$ inhibits secretion of interferon- $\gamma$ by mitogen- and antigen-stimulated bovine mononuclear leukocytes. Vet. Immunol. Immunopathol. 52:77-90.

Ametaj, B. N., B. J. Nonnecke, R. L. Horst, and D. C. Beitz. 2000. Effects of retinoic acid and 1,25-dihydroxyvitamin $\mathrm{D}_{3}$ on IFN- $\gamma$ secretion by mononuclear leukocytes from nulliparous and postparturient dairy cattle. Int. J. Vitam. Nutr. Res. 70:92-101.

Brandon, M. R., D. L. Watson, and A. K. Lascelles. 1971. The mechanism of transfer of immunoglobulin into the mammary secretion of cows. Aust. J. Biol. Med. Sci. 49:613-623.

Burton, J. L., and M. E. Kehrli, Jr. 1996. Effects of dexamethasone on bovine circulating T lymphocyte populations. J. Leuk. Biol. 59:90-99.

Daynes, R. A., E . Y. Enioutina, S. Butler, H. H. Mu, Z. A. McGee, and B. A. Araneo. 1996. Induction of common mucosal immunity by hormonally immunomodulated peripheral immunization. Infect. Immun. 64:1100-1109.

Detilleux, J. C., M. E. Kehrli Jr., J. R. Stabel, A. E. Freeman, and D. H. Kelley. 1995. Study of immunological dsyfunction in periparturient Holstein cattle selected for high and average milk production. Vet. Immunol. Immunopathol. 44:251-267.

Franklin, S. T., J. W. Young, and B. J. Nonnecke. 1994. Proliferation and phenotype of bovine mononuclear leukocytes in cultures stimulated by pokeweed mitogen. J. Dairy Sci. 77:3592-3600.

Goff, J. P., K. Kimura, and R. L. Horst. 2002. Effect of mastectomy on milk fever, energy, and vitamin $\mathrm{A}, \mathrm{E}$, and $\beta$-carotene status at parturition. J. Dairy Sci. 85:1427-1436.

Ishikawa, H. 1987. Observation of lymphocyte function in perinatal cows and neonatal calves. Jpn. J. Vet. Sci. 49:469-475.

Kashiwazaki, Y., Y. Maede, and S. Namioka. 1985. Transformation of bovine blood lymphocytes in the perinatal period. Jpn. J. Vet. Sci. 47:337-339.

Kehrli, M. E., Jr., and J. P. Goff. 1989. Periparturient hypocalcemia in cows: Effects on peripheral neutrophil and lymphocyte function. J. Dairy Sci. 72:1188-119.

Kehrli, M. E., Jr., and J. A. Harp. 2001. Immunity in the mammary gland. Vet. Clin. North Am. [Food Anim Pract] 17:495-516.

Kehrli, M. E., Jr., B. J. Nonnecke, and J. A. Roth. 1989a. Alterations in bovine neutrophil function during the periparturient period. Am. J. Vet. Res. 50:207-214.

Kehrli, M. E., Jr., B. J. Nonnecke, and J. A. Roth. 1989b. Alterations in bovine lymphocyte function during the periparturient period. Am. J. Vet. Res. 50:215-220.

Kimura, K., J. P. Goff, M. E. Kehrli, Jr., and J. A. Harp. 1999. Phenotype analysis of peripheral blood mononuclear cells in periparturient cows. J. Dairy Sci. 82:315-319.

Kimura, K., J. P. Goff, M. E. Kehrli, Jr., J. A. Harp, and B. J. Nonnecke. 2002. Effects of mastectomy on the composition of peripheral blood mononuclear cell populations in periparturient dairy cows. J. Dairy Sci. 85:1437-1444.

Mallard, B. A., J. C. Dekkers, M. J. Ireland, K. E. Leslie, S. Sharif, C. L. Vankampen, and B. N. Wilkie. 1998. Alteration in immune responsiveness during the peripartum period and its ramification on dairy cow and calf health. J. Dairy Sci. 81:585-595. 
Nagahata, H., A. Ogawa, Y. Sanada, H. Noda, and S. Yamamoto. 1992. Peripartum changes in antibody producing capacity of lymphocytes from dairy cows. Vet Q. 14:39-40.

Nonnecke, B. J., J. L. Burton, and M. E. Kehrli, Jr. 1997. Associations between function and composition of blood mononuclear leukocyte populations from Holstein cattle treated with dexamethasone. J. Dairy Sci. 80:2403-2410.

Nonnecke, B. J., S. T. Franklin, and S. L. Nissen. 1991. Leucine and its catabolites alter mitogen-stimulated DNA-synthesis by bovine lymphocytes. J. Nutr. 121:1665-1672.

Nonnecke, B. J., S. T. Franklin, T. A. Reinhardt, and R. L. Horst. 1993. In vitro modulation of proliferation and phenotype of resting and mitogen-stimulated bovine mononuclear leukocytes by 1,25 dihydroxyvitamin $\mathrm{D}_{3}$. Vet. Immunol. Immunopathol. 38:75-89.

Nonnecke, B. J., S. T. Franklin, and J. W. Young. 1992. Effects of ketones, acetate, and glucose on immunoglobulin secretion by bovine lymphocytes. J. Dairy Sci. 75:982-990.

Nonnecke, B. J., and R. L. Horst. 1992. 1,25-Dihydroxyvitamin $\mathrm{D}_{3}$ enhancement of in vitro immunoglobulin secretion by mitogenstimulated bovine lymphocytes. Immunol. Infect. Dis. 2:185-189.

Preisler, M. T., P. S. Weber, R. J. Tempelman, R. J. Erskine, H. Hunt, and J. L. Burton. 2000. Glucocorticoid receptor expression profiles in mononuclear leukocytes of periparturient Holstein cows. J. Dairy Sci. 83:38-47.
Reinhardt, T. A., J. R. Stabel, and J. P. Goff. 1999. 1,25-Dihydroxyvitamin $\mathrm{D}_{3}$ enhances milk antibody titers to Escherichia coli J5 vaccine. J. Dairy Sci. 82:1904-1909.

Sordillo, L. M., G. M. Pighetti, and M. R. Davis. 1995. Enhanced production of bovine tumor necrosis factor-alpha during the periparturient period. Vet. Immunol. Immunopathol. 49:263-270.

Sordillo, L. M., M. J. Redmond, M. Compos, L. Warren, and L. A. Babiuk. 1991. Cytokine activity in bovine mammary gland secretions during the periparturient period. Can. J. Vet. Res. 55:298-301.

Sordillo, L. M., K. Shafer-Weaver, and D. DeRosa. 1997. Immunobiology of the mammary gland. J. Dairy Sci. 80:1851-1865.

Stabel, J. R., M. E. Kehrli, Jr., J. R. Thurston, J. P. Goff, and T. C. Boone. 1991. Granulocyte colony-stimulating factor effects on lymphocytes and immunoglobulin concentrations in periparturient cows. J. Dairy Sci. 74:3755-3762.

Yang, T. J., I. A. Ayoub, and M. J. Rewinski. 1997. Lactation stagedependent changes of lymphocyte subpopulations in mammary secretion: Inversion of $\mathrm{CD} 4+/ \mathrm{CD} 8+\mathrm{T}$ cell ratios at parturition. Am. J. Reprod. Immunol. 37:378-383.

Van Kampen, C., and B. A. Mallard. 1997. Effects of peripartum stress and health on circulating lymphocyte subsets. Vet. Immunol. Immunopathol. 59:79-91.

Wegman, T. G., H. Lin, L. Guilbert, and T. R. Mosmann. 1993. Bidirectional cytokine interactions in the maternal-fetal relationship: Is pregnancy a TH2 phenomenon? Immunol. Today 14:353-356. 